\title{
Uncomplicated Urinary Tract Infections
}

Florian M. E. Wagenlehner, Udo Hoyme, Martin Kaase, Reinhard Fünfstück, Kurt G. Naber, Guido Schmiemann

\section{SUMMARY}

Background: Urinary tract infections (UTIs) are among the most common types of bacterial infection in outpatient medicine. Rising rates of antibiotic resistance and a better understanding of the ecological adverse effects (collateral damage) of antibiotics warrant a reevaluation of the treatment recommendations for uncomplicated UTI. The new S3 guideline contains updated recommendations.

Methods: The new S3 guideline is based on a review of publications on uncomplicated UTI retrieved by a systematic search of the Medline and Cochrane Library databases. Guidelines from abroad were also considered in the review.

Results: Uncomplicated UTI is classified as either uncomplicated cystitis (UC) or uncomplicated pyelonephritis (UP). The choice of a suitable antibiotic is determined by the following main criteria: the patient's individual risk profile and prior antibiotic treatment, if any; the spectrum of pathogens and antibiotic susceptibility; the proven efficacy of the antibiotic; the ecological adverse effects (collateral damage) of antimicrobial therapy; the side effects for the patient under treatment. On the basis of these criteria, co-trimoxazole/trimethoprim and fluoroquinolones can no longer be recommended as first-line empirical treatment for UC. Rather, the new recommended treatment of first choice consists of fosfomycin-trometamol, nitrofurantoin, or pivmecillinam. High-dose fluoroquinolones are still recommended, however, as first-line oral treatment for UP. Asymptomatic bacteriuria should only be treated in exceptional situations such as pregnancy or before urological procedures that will probably injure the mucosa of the urinary tract.

Conclusion: The new S3 guideline on uncomplicated UTI incorporates a forward-looking approach to the use of antibiotics in treating this common type of infection. It is intended to bring about a sustained improvement in the quality of care.

\section{Cite this as:}

Wagenlehner FME, Hoyme U, Kaase M, et al.: Clinical practice guideline: uncomplicated urinary tract infections. Dtsch Arztebl Int 2011; 108(24): 415-23. DOI: 10.3238/arztebl.2011.0415

\footnotetext{
Klinik und Poliklinik für Urologie, Kinderurologie und Andrologie, Justus-Liebig-Universität, Giessen: Prof. Dr. med. Wagenlehner

Klinik für Frauenheilkunde und Geburtshilfe, Helios Klinikum Erfurt GmbH, Erfurt: Prof. Dr. med. Hoyme

Abteilung Medizinische Mikrobiologie, Ruhr-Universität Bochum, Bochum: Dr. med. Kaase

Klinik für Innere Medizin I, Sophien- und Hufeland-Klinikum GmbH, Weimar: Prof. Dr. med. Fünfstück

Straubing: Prof. Dr. med. Dr. h. c. Naber

Institut für Allgemeinmedizin, Medizinische Hochschule, Hannover: Dr. med. Schmiemann
}

U ncomplicated urinary tract infections (UTIs) are among the most frequently encountered infections in the outpatient setting. After respiratory tract infections, they are the most common reason why antibiotics are prescribed. Uncomplicated UTIs include acute uncomplicated cystitis (AUC) and acute uncomplicated pyelonephritis (AUP). Recently, the level of resistance of pathogens causing uncomplicated UTI has risen significantly. In addition, the medical world has become more conscious of the collateral effects of systemically applied antibiotics. Different antibiotic agents exert a variety of selective pressures on both the pathogens involved in the infection and the innocentbystander flora at the same site. Recognition of this fact has led to an international re-evaluation of therapeutic recommendations in uncomplicated UTI (1-3).

The S3 guidelines for UTIs are intended to implement evidence-based guidelines with reference to:

- Diagnosis and treatment of uncomplicated UTI

- Rational use of antimicrobial substances

- Avoiding the unbalanced use of particular antibiotic classes, and thus

- Preventing the development of resistance.

The present publication focuses on the recommendations regarding the epidemiology, treatment, and management of uncomplicated bacterial UTI acquired in the outpatient setting in adult patients. Diagnosis was covered in an earlier publication (4). This paper is aimed mainly at general practitioners, gynecologists, infectologists, specialists in internal medicine working in general practice, microbiologists, nephrologists, and urologists.

\section{Methods}

The S3 Guideline consensus group consists of 11 representatives of 7 medical societies and one patient representative (Box 1 ). Topics were defined and then distributed among subgroups for further elaboration. The method of the literature search and the search strategy are presented in the eTable. An appraisal of the most recent literature data in relation to the recommendations of this guideline is shown in Box 2. Recommendations are evaluated and graded to one of five evidence grades (5) (Table 1); this grading closely followed the procedure for the development of national care guidelines. The following four recommendations were employed:

- A: Strong recommendation

- B: Recommendation

- C: Recommendation inconclusive

- D: No statement possible. 
BOX 1

\section{Guideline group}

Professional body / work group / organization and voting authors

- German Society of Urology (DGU, Deutsche Gesellschaft für Urologie) (lead organization)

- Prof. Dr. Dr. K.G. Naber

- Dr. W. Vahlensieck

- Prof. F.M.E. Wagenlehner

- German Society for General and Family Medicine (DEGAM, Deutsche Gesellschaft für Allgemeinmedizin und Familienmedizin)

- Prof. E. Hummers-Pradier

- Dr. G. Schmiemann

- German Society of Gynecology and Obstetrics (DGG, Deutsche Gesellschaft für Gynäkologie und Geburtshilfe)

- Prof. U. Hoyme

- Prof. D. Watermann

- German Society for Hygiene and Microbiology (DGHM, Deutsche Gesellschaft für Hygiene und Mikrobiologie)

- Dr. M. Kaase

- Dr. E. Kniehl

- German Society for Infectiology (DGI, Deutsche Gesellschaft für Infektiologie) - Prof. Dr. Dr. K.G. Naber

- German Society of Nephrology (DGFN, Deutsche Gesellschaft für Nephrologie) - Prof. R. Fünfstück

- Dr. U. Sester

- Paul Ehrlich Society for Chemotherapy (PEG, Paul-Ehrlich-Gesellschaft für Chemotherapie)

- Prof. R. Fünfstück

- Dr. M. Kaase

- Dr. E. Kniehl

- Prof. Dr. Dr. K.G. Naber

- Prof. F.M.E.Wagenlehner

Patient representative

- I. Selbach
The evidence-based recommendations were developed in the framework of 11 consensus conferences. Formal consensus was achieved through the nominal group process (NGP) under the guidance of an external moderator from the Association of Scientific Medical Societies in Germany (AWMF, Arbeitsgemeinschaft der Wissenschaftlichen Medizinischen Fachgesellschaften) with the representatives of the participating medical associations. The process of development of the S3 Guideline is illustrated in Figure 1. The full consensus-approved S3 Guideline is available in short and long versions from the websites of the AWMF (6-8), the German Society of Urology (DGU, Deutsche Gesellschaft für Urologie) (9), and other participating societies.

\section{Definition}

A UTI is classified as uncomplicated if there are no functional or anatomical anomalies in the urinary tract, no renal functional impairment, and no concomitant disease that would promote the UTI (3). A lower UTI (AUC) is taken to be present when symptoms are restricted to the lower urinary tract, e.g., pain on micturition (dysuria), urgency, pollakisuria, or pain above the symphysis. An upper UTI (AUP) is present when symptoms also include, for example, flank pain, pain on percussion of the renal area, and/or fever $\left(>38{ }^{\circ} \mathrm{C}\right)(3)$. A distinction is made between clinically symptomatic UTI and asymptomatic bacteriuria (ASB).

The following patient groups with uncomplicated UTI may be distinguished for diagnostic and therapeutic purposes (2):

- Otherwise healthy, nonpregnant premenopausal women (standard group)

- Otherwise healthy pregnant women

- Otherwise healthy postmenopausal women

- Men with uncomplicated UTI

- Patients with diabetes mellitus.

\section{Treatment}

In placebo-controlled studies of AUC, a spontaneous clinical cure rate of $25 \%$ to $42 \%$ was shown. Metaanalysis, however, showed significantly higher symptomatic and bacteriological cure rates and better prevention of reinfection when antibiotic treatment was given (10). The size of effect of antibiotic treatment in the placebo-controlled studies was shown by a number needed to treat (NNT) of 3 to $4(11,12)$.

AUC usually has a benign course. If an uncomplicated UTI remains confined to the urinary bladder, no serious complications need be anticipated even with repeated episodes. The risk that a patient with AUC that is not effectively treated will go on to develop AUP is only around $2 \%$ (12). Hence, the main object in treating AUC is to achieve more rapid symptom relief. For this reason, the preferred option is as short a course as possible of appropriate antibiotic treatment. In their minority vote the representatives of the German Association for General and Family Medicine (DEGAM, Deutsche Gesellschaft für Allgemeinmedizin und Familienmedizin) 
also give symptomatic treatment without antibiotics as a treatment option.

In AUP, the aim of antibiotic treatment is also to prevent further systemic involvement in the infection, and therefore in this case effective antibiotic treatment should be started as soon as possible.

In ASB, antibiotic treatment is rarely indicated. ASB increases the risk of infection only in patients undergoing a urinary tract intervention that is expected to cause mucosal injury, and in pregnant women. In these cases, therefore, an ASB should be sought and, if found, treated.

\section{Choice of antibiotic}

An appropriate antibiotic is chosen according to the following cardinal criteria:

- Patient's individual risk and previous antibiotic treatment

- Pathogen spectrum and antibiotic sensitivity

- Effectiveness of the antimicrobial agent

- Effects on the resistance situation in the patient and/or ecological effects (collateral damage)

- Undesired drug effects.

Patient's individual risk and previous antibiotic treatment-The individual risks of the patient, in addition to a specific allergy to an antibiotic agent, also include previous treatment with a specific antibiotic agent or a previous stay in hospital (13). In the case of previous antibiotic treatment, there may be a higher probability of resistance to the agent used. In AUC, treatment with trimethoprim/sulfamethoxazole within the previous 6 months has been shown to be an independent predictor of resistance to trimethoprim/sulfamethoxazole (14). Likewise, resistance against fluoroquinolones is significantly higher in patients who have received treatment with fluoroquinolones within the past 12 months (13).

Pathogen spectrum and antibiotic sensitivity-Most uncomplicated UTIs are caused by E. coli. The pathogen spectrum and antibiotic sensitivity form the basis for the choice of antibiotic. Antibiotic sensitivity is a highly dynamic process and subject to local fluctuations and differences over time. In general, treatment of AUC is carried out without bacteriological evidence; routine sensitivity tests are not at present carried out in unselected patients. Conclusions about changes in the resistance situation can therefore only be drawn from studies. The most recent resistance study for Germany showed increasing antibiotic resistance rates in pathogens of uncomplicated UTI (15). The resistance of $E$. coli to ampicillin or trimethoprim/sulfamethoxazole was $60 \%$ and $30 \%$ respectively, and resistance to the fluoroquinolones almost $10 \%$ - markedly higher than in previous years. From the resistance rates to nalidixine acid it may be inferred that $10 \%$ and $30 \%$ of $E$. coli isolates from, respectively, primary and recurrent UTIs have already acquired resistance genes to fluoroquinolones as well (first-step resistance), although the sensitivity testing still gave values showing sensitivity to fluoroquinolones. E. coli showed sensitiv-

\section{BOX 2}

\section{Recent results in the literature}

Since this guideline was finalized, Cochrane Reviews on the treatment of uncomplicated urinary tract infections (UTIs) (25), the duration of antibiotic treatment in older female patients (e1), and the treatment of asymptomatic bacteriuria during pregnancy have been published (e2). The studies came to the conclusion that in both older female patients and during pregnancy, a shorter duration of treatment is probably adequate.

The significance of collateral damage is supported by the results of another systematic review (e3). This study showed that using antibiotics to treat uncomplicated UTI increases the risk of development of resistance not only in the general population but in the individual patient.

The treatment option of delayed prescription can reduce the rate of antibiotic prescriptions (e4).

A pilot study of 80 women with uncomplicated cystitis showed that treatment with ibuprofen is not inferior to treatment with ciprofloxacin (e5). To what extent nonantibiotic therapy is an alternative needs to be investigated in further studies.

ity rates to fosfomycin, nitrofurantoin, and mecillinam that were still below $10 \%$.

No such studies exist in relation to AUP, but because the pathogen spectrum for AUP is very similar to that for uncomplicated cystitis, the recommendations for empirical treatment are based on the resistance rates from the studies on AUC. A sensible resistance threshold for the recommendation of empirical treatment for AUC, according to a consensus recommendation based on empirical treatment with co-trimoxazole/trimethoprim, is $20 \%$ (16). Above this resistance threshold, the risk of treatment failure outweighs the possible advantages of such a treatment.

For empirical treatment of severe infections such as AUP, early effective antibiotic treatment is important in order to minimize disease progression. For this reason, a lower threshold value of about $10 \%$ is used for the recommendation of empirical antibiotic treatment.

Since there are significant local and temporal differences in the resistance of uncomplicated UTI pathogens, physicians treating UTIs need to seek out information about the current resistance situation in their own area. Sources of such information include national studies, evaluations by the collaborating laboratory, and their own data. In such statistical studies care should be taken to ensure that the data are representative of uncomplicated UTI, since otherwise the resistance situation may be overestimated (17). 
TABLE 1

Evidence grade (I-V) according to the Oxford Centre of Evidence Based Medicine (1999) (5)-Studies of Treatment/Prevention/Etiology

\begin{tabular}{|c|c|}
\hline $\begin{array}{l}\text { Evidence } \\
\text { grade }\end{array}$ & Description \\
\hline la & $\begin{array}{l}\text { Systematic review of randomized controlled } \\
\text { studies (RCTs) }\end{array}$ \\
\hline lb & $\begin{array}{l}\text { A well-planned RCT (with narrow confi- } \\
\text { dence interval) }\end{array}$ \\
\hline Ic & All-or-none principle \\
\hline Ila & $\begin{array}{l}\text { Systematic review of well-planned cohort } \\
\text { studies }\end{array}$ \\
\hline$\| \mathrm{lb}$ & $\begin{array}{l}\text { A well-planned cohort study or a poor- } \\
\text { quality RCT }\end{array}$ \\
\hline Ilc & $\begin{array}{l}\text { Outcome and effect studies, pharmaco- } \\
\text { economic and ecological studies }\end{array}$ \\
\hline Illa & $\begin{array}{l}\text { Systematic review of well-planned case- } \\
\text { control studies }\end{array}$ \\
\hline IIIb & A case-control study \\
\hline IV & $\begin{array}{l}\text { Case series or poor-quality cohort and } \\
\text { case-control studies }\end{array}$ \\
\hline V & $\begin{array}{l}\text { Expert opinion without explicit critical } \\
\text { appraisal of the evidence or based on } \\
\text { physiological models/laboratory research }\end{array}$ \\
\hline
\end{tabular}

Effectiveness of the antimicrobial agent-For treatment of AUC, randomized treatment studies have shown that co-trimoxazole/trimethoprim were as effective as fluoroquinolones, fosfomycin trometamol, nitrofurantoin, and pivmecillinam, but these antibiotics were more effective than cephalosporins and aminopenicillins (2). For oral therapy of AUP, the studies showed greater effectivity of fluoroquinolones versus the cephalosporins, and the latter were more effective than co-trimoxazole/trimethoprim, and these in turn were more effective than aminopenicillins (2).

Effects on the patient's resistance status and/or ecological effects (collateral damage)_-Important criteria for a forward-looking antibiotic policy are the effects of antibiotics on the resistance status of the patient and/or ecological effects (collateral damage). This refers to the epidemiological influence of antibiotics on the bacterial flora that play no causative role in the infection, such as the bacterial flora of the gastrointestinal tract or the skin.

Within the group of orally administered antibiotics that are in principle appropriate for treatment of uncomplicated UTIs, fluoroquinolones and cephalosporins are associated with the highest risk of bacteriological collateral damage in the form of selection of multiresistant pathogens or of increased risk of Clostridium difficile-associated colitis (18). Such effects have so far not been shown for fosfomycin, nitrofurantoin, or mecillinam.

\section{FIGURE 1}

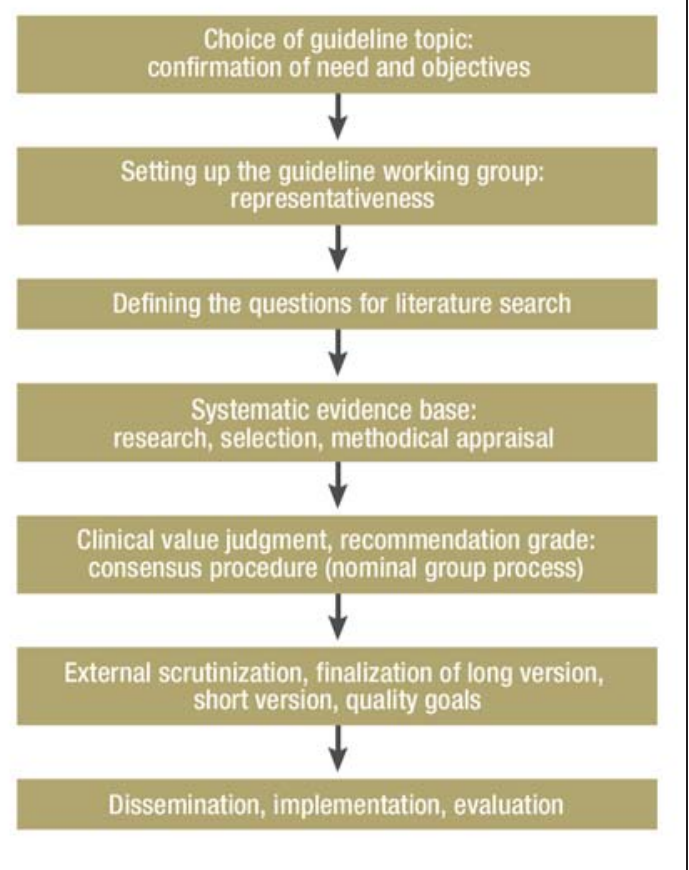

Development of the \$3 Guideline on Uncomplicated Urinary Tract Infections (2)

In addition, because fluoroquinolones and cephalosporins need to be used for other indications as well, the clinical consequence of increased resistance to these agents must be regarded as more serious than increased resistance to the other antibiotics mentioned. For this reason, so long as alternative therapies with comparable efficacy and acceptable side effect profiles exist, fluoroquinolones and cephalosporins should not be used as first-line antibiotics in uncomplicated cystitis.

Undesired drug effects-All the drugs mentioned for acute and short-term therapy of UTIs have a low level of adverse effects. With nitrofurantoin, severe adverse effects such as lung damage are generally not expected until after a treatment duration of at least 6 months (19).

\section{Treatment of acute uncomplicated cystitis}

On the basis of the criteria that have been outlined, the drugs listed in Table 2 may now be recommended at the doses shown for oral first-line treatment of AUC in otherwise healthy premenopausal women (2). Different treatment recommendations are given in the full-length guideline for the other patient groups $(2,7)$. The drugs of first choice are fosfomycin trometamol, nitrofurantoin, and pivmecillinam, since $E$. coli is highly sensitive to these antibiotics and they cause little collateral damage. In the summary of product characteristics, the use of nitrofurantoin is given a restricted recommendation. 
According to this, nitrofurantoin should only be given when more effective and less risky antibiotics or chemotherapeutics cannot be used. Pivmecillinam is currently not available in Germany, but it is in some other neighboring European countries such as Austria and the Scandinavian countries. This guideline recommendation also takes account of the increasing development of resistance to fluoroquinolones and cephalosporins, and aims to reduce the selection pressure on these active substances.

Fosfomycin trometamol, nitrofurantoin, and pivmecillinam are mainly used for the treatment of AUC. Co-trimoxazole/trimethoprim, fluoroquinolones, cephalosporins, and aminopenicillins in combination with a beta-lactamase inhibitor should only be used as an empirical alternative when the local resistance status $(<20 \%)$ allows and first-line drugs cannot be used. However, this requires knowledge of local resistance statistics in uncomplicated UTI. In their minority vote the DEGAM representatives continue also to recommend trimethoprim as a first-line drug.

A follow-up of treatment outcome in AUC in an otherwise healthy premenopausal woman is not required if she is free of symptoms. If treatment fails (within 2 weeks), possible factors to consider are lack of compliance, resistant pathogens, and any hitherto unknown risk factors. In these cases, before the next attempt at treatment, the patient should be carefully examined and reminded of the importance of following all instructions for treatment, the urine should be tested (including culture), and possibly the antibiotic should be changed.

During pregnancy, the main drugs that may be used to treat AUC are fosfomycin trometamol or group 2 or 3 oral cephalosporins.

\section{Treatment of acute uncomplicated pyelonephritis}

The antibiotics recommended for use for oral first-line treatment of AUP are listed in Table 3; the clinical procedure is summarized in Figure 2 (2).

Mild to moderate pyelonephritic infections in otherwise healthy premenopausal women should be treated with oral antibiotics. In severe infections with systemic accompanying symptoms such as nausea, vomiting, and dizziness, therapy should start with high-dose parenteral antibiotics. A two-week course is generally sufficient for mild or moderate AUP that follows a normal course in an otherwise healthy premenopausal woman. If fluoroquinolones are used, the treatment can be reduced to 7 to 10 days, and if given at a higher dose - e.g., levofloxacin $750 \mathrm{mg}$ once daily - even to 5 days. Fluoroquinolones should be regarded as the drug of first choice if the local $E$. coli resistance rate is below $10 \%$. Treatment with cefpodoxime proxetil should be considered in situations where, for example, fluoroquinolones cannot be used. Co-trimoxazole should no longer be used for empirical treatment of AUP. However, co-trimoxazole may be considered for oral treatment following parenteral treatment if the pathogen has been shown to be sensitive to this substance.

\section{TABLE 2}

Recommended empirical short-term treatment of uncomplicated cystitis in otherwise healthy premenopausal women (no risk factors) (2)

\begin{tabular}{|c|c|c|}
\hline Agent & Daily dose & Duration \\
\hline \multicolumn{3}{|l|}{ First-line drugs (A) } \\
\hline $\begin{array}{l}\text { Fosfomycin } \\
\text { trometamol }\end{array}$ & $3000 \mathrm{mg} 1 \times$ & 1 day \\
\hline Nitrofurantoin*1 & $50 \mathrm{mg} 4 \times$ daily & 7 days \\
\hline Nitrofurantoin $\mathrm{ER}^{* 1}$ & $100 \mathrm{mg} 2 \times$ daily & 5 days \\
\hline Pivmecillinam*2 & $200 \mathrm{mg} 2 \times$ daily & 7 days \\
\hline Pivmecillinam ${ }^{* 2}$ & $400 \mathrm{mg} 2 \times$ daily & 3 days \\
\hline \multicolumn{3}{|c|}{ Second-line drugs (B) } \\
\hline Ciprofloxacin & $250 \mathrm{mg} 2 \times$ daily & 3 days \\
\hline Ciprofloxacin ER & $500 \mathrm{mg} 1 \times$ daily & 3 days \\
\hline Levofloxacin & $250 \mathrm{mg} 1 \times$ daily & 3 days \\
\hline Norfloxacin & $400 \mathrm{mg} 2 \times$ daily & 3 days \\
\hline Ofloxacin & $200 \mathrm{mg} 2 \times$ daily & 3 days \\
\hline $\begin{array}{l}\text { Cefpodoxime } \\
\text { proxetil }\end{array}$ & $100 \mathrm{mg} 2 \times$ daily & 3 days \\
\hline \multicolumn{3}{|c|}{$\begin{array}{l}\text { With knowledge of the local resistance situation (E. col } \\
\text { resistance }<20 \% \text { ) (B) }\end{array}$} \\
\hline Co-trimoxazole & $\begin{array}{l}160 / 800 \mathrm{mg} \\
2 \times \text { daily }\end{array}$ & 3 days \\
\hline Trimethoprim*3 & $200 \mathrm{mg} 2 \times$ daily & 5 days \\
\hline
\end{tabular}

${ }^{* 1}$ In the summary of product characteristics the use of nitrofurantoin is restricted as follows: "Nitrofurantoin may only be given when more effective and lower-risk antibiotics or chemotherapeutics cannot be used." (www.fachinfo.de 13.02. 2007)

*2 Pivmecillinam is currently unavailable in Germany, but is available in some neighboring European countries (e.g., Austria, the Scandinavian countries) ${ }^{* 3}$ In their minority vote the representatives of the German Society for General and Family Medicine (DEGAM, Deutsche Gesellschaft für Allgemeinmedizin und

Familienmedizin) continue also to recommend trimethoprim as a first-line drug

Group 2 or 3 cephalosporins are recommended for treatment of pyelonephritis during pregnancy. During pregnancy, hospital admission for treatment should be considered. After treatment of AUP during pregnancy, a urine culture should be carried out to confirm the success of treatment, as ASB during pregnancy should be treated.

\section{Treatment of asymptomatic bacteriuria}

The situation when there is evidence of bacteriuria without clinical symptoms (ASB) is quite different. Studies have shown that it is worth treating this condition only in pregnant women and patients in whom a urinary tract intervention is intended that may be expected to damage the mucosa $(2,20)$. For this reason, ASB is tested for and, if found, treated only in these patients. For the following groups, ASB evidently has no deleterious consequences and therefore does not need to be diagnosed and treated $(2,20)$ : 
TABLE 3

Recommended empirical antibiotic treatment of uncomplicated pyelonephritis in otherwise healthy premenopausal women (no risk factors) (2)

\begin{tabular}{l|l|l}
\hline Oral therapy for mild to moderate infection & \multicolumn{2}{l}{} \\
\hline First-line drugs $(\mathbf{A})^{* 4}$ & Daily dose & Duration \\
\hline Ciprofloxacin*1 & $500-750 \mathrm{mg} 2 \times$ daily & $7-10$ days \\
\hline Ciprofloxacin ER & $1000 \mathrm{mg} 1 \times$ daily & $7-10$ days \\
\hline Levofloxacin $^{* 1}$ & $(250-) 500 \mathrm{mg} 1 \times$ daily & $7-10$ days \\
\hline Levofloxacin & $750 \mathrm{mg} 1 \times$ daily & 5 days
\end{tabular}

Second-line drugs (B) (same clinical efficacy, bacteriologically not as effective as fluoroquinolones)

\begin{tabular}{l|l|l} 
Cefpodoxime proxetil & $200 \mathrm{mg} 2 \times$ daily & 10 days \\
\hline Ceftibuten & $400 \mathrm{mg} 1 \times$ daily & 10 days
\end{tabular}

In cases of known pathogen sensitivity (B) (not for empirical treatment)

\begin{tabular}{l|l|l} 
Co-trimoxazole & $160 / 800 \mathrm{mg} 2 \times$ daily & 14 days \\
\hline Amoxicillin/clavulanate $^{* 2, * 3}$ & $0.875 / 0.125 \mathrm{~g} 2 \times$ daily & 14 days \\
\hline Amoxicillin/clavulanate $^{* 2, * 3}$ & $0.5 / 0.125 \mathrm{~g} 3 \times$ daily & 14 days
\end{tabular}

Initial parenteral therapy in severe infection

After clinical improvement, in cases with known pathogen sensitivity, oral follow-on treatment using one of the treatment regimes given above may be started. Total treatment duration is 1 to 2 weeks; for this reason, no duration is given for the parenteral antibiotic treatment.

\begin{tabular}{|c|c|}
\hline First-line drugs $(\mathrm{A})^{* 4}$ & Daily dose \\
\hline Ciprofloxacin & $400 \mathrm{mg} 2 \times$ daily \\
\hline Levofloxacin*1 & (250-) $500 \mathrm{mg} 1 \times$ daily \\
\hline Levofloxacin & $750 \mathrm{mg} 1 \times$ daily \\
\hline \multicolumn{2}{|l|}{ Second-line drugs (B) } \\
\hline Cefepime*1,*5 & $1-2$ g $2 \times$ daily \\
\hline Ceftazidime ${ }^{* 2}$ & $1-2$ g $3 \times$ daily \\
\hline Ceftriaxone $e^{* 1, * 5}$ & $1-2 \mathrm{~g} 1 \times$ daily \\
\hline Cefotaxime $^{\star 2}$ & $2 \mathrm{~g} 3 \times$ daily \\
\hline Amoxicillin/clavulanate ${ }^{* 2, * 3}$ & $1 / 0.2 \mathrm{~g} 3 \times$ daily \\
\hline Ampicillin/sulbactam ${ }^{22, * 3}$ & $1 / 0.5 \mathrm{~g} 3 \times$ daily \\
\hline Piperacillin/tazobactam ${ }^{* 1, * 5}$ & 2/0.5-4/0.5 g $3 \times$ daily \\
\hline Amikacin & $15 \mathrm{mg} / \mathrm{kg} 1 \times$ daily \\
\hline Gentamicin & $5 \mathrm{mg} / \mathrm{kg} 1 \times$ daily \\
\hline Doripenem ${ }^{* 5, * 6}$ & $0.5 \mathrm{~g} 3 \times$ daily \\
\hline Ertapenem $* 5, * 6$ & $1 \mathrm{~g} 1 \times$ daily \\
\hline Imipenem/cilastatin $* 5, * 6$ & $0.5 / 0.5 \mathrm{~g} 3 \times$ daily \\
\hline Meropenem $* 5, * 6, * 7$ & $1 \mathrm{~g} 3 \times$ daily \\
\hline
\end{tabular}

${ }^{*}$ Low dose studied, high dose recommended by experts * 2 Not studied as a monoagent in acute uncomplicated pyelonephritis ${ }^{*}{ }^{3}$ Especially for Gram-positive pathogens ${ }^{*}$ If $E$. coli resistance is $<10 \%$ ${ }^{*} 5$ Same protocol for acute uncomplicated pyelonephritis and complicated urinary tract infections (stratification not always possible) ${ }^{*}$ Only when ESBL (extended-spectrum beta-lactamase) resistance is $>10 \%$.

${ }^{* 7}$ Only studied at high dose
- Nonpregnant premenopausal women

- Women with diabetes mellitus (with good metabolic control)

- Older people living at home

- Older people living in homes

- Patients who have suffered spinal cord injury

- Patients with indwelling catheters.

\section{Guideline implementation in care}

Because it is done so often, treating uncomplicated UTIs with antibiotics exerts enormous selective pressure not only on the bacteria involved, but also on the collateral flora, resulting in a significant influence on the selection of antibiotic-resistant bacteria. For this reason, it is extremely important to exercise caution in the prescription of antibiotics in this area of medicine, in order to ensure the long-term efficacy of antibiotic treatment.

The evidence- and consensus-based recommendations of the Guideline on Uncomplicated Urinary Tract Infections need broad implementation among all professional groups involved in managing UTIs, to achieve better care and thus to ensure a forwardlooking antibiotic policy for these frequent infections.

Tried and tested instruments of support for implementation are publications in medical journals and on the websites of the participating medical societies, which can also include adjustments for regional differences and different levels of care (21). User versions have been developed for the various individual societies (22-24).

In addition, the implementation of guidelines can be supported by the guidelines' own quality indicators. The present S3 guideline puts forward suggestions for possible structural, process, and outcome indicators which have yet to be validated in practice.

Guidelines are subject to a dynamic development and need to be constantly updated. An update of the S3 Guideline for Urinary Tract Infections is planned for 2015 .

\section{International reviewers}

Truls E. Bjerklund Johansen (Denmark), Frank Buntinx (Belgium), Geert Jan Dinant (Netherlands), Ellen Stobberingh (Netherlands), Arjana Tambic Andrasevic (Croatia), Björn Wullt (Sweden)

\section{Coordination and external moderation}

Ina Kopp, AWMF-Institut für medizinisches Wissensmanagement, PhillipsUniversität, Marburg, Germany

\section{Support in producing the manuscript}

Cordula Lebert

\section{Conflict of interest statement}

Prof. Wagenlehner has a relationship with the following entities: Astellas, Bayer-Vital, Calixa, Cerexa, Cernelle, Cubist, GSK, MerLion, OM-Pharma, Janssen-Cilag, Johnson and Johnson, Lilly, Pharmacia, Pierre Fabre, RosenPharma, Sanofi-Aventis, Strathmann, Zambon, Serag Wiessner.

Prof. Hoyme, via his employer, has consultancy contracts with the following: Jenapharm, Schering-Bayer, Wolff, Kade, Novartis, Chugai, Sanofi Pasteur MSD, Infectopharm, Roche Diagnostics, Nestlé, Mikrogen, 3 M Pharma, and Hoffmann-La Roche.

Dr. Kaase has received lecture fees from Roche Diagnostics and bioMérieux and has had conference fees paid by from Wyeth.

Prof. Fünfstück has received lecture fees and reimbursement of travel expenses from MSD, Lilly-Pharma Deutschland, Novartis Pharma, KirchheimVerlag, Rosen-Pharma, and was co-author of a report for Pierre-Fabre Pharma. 


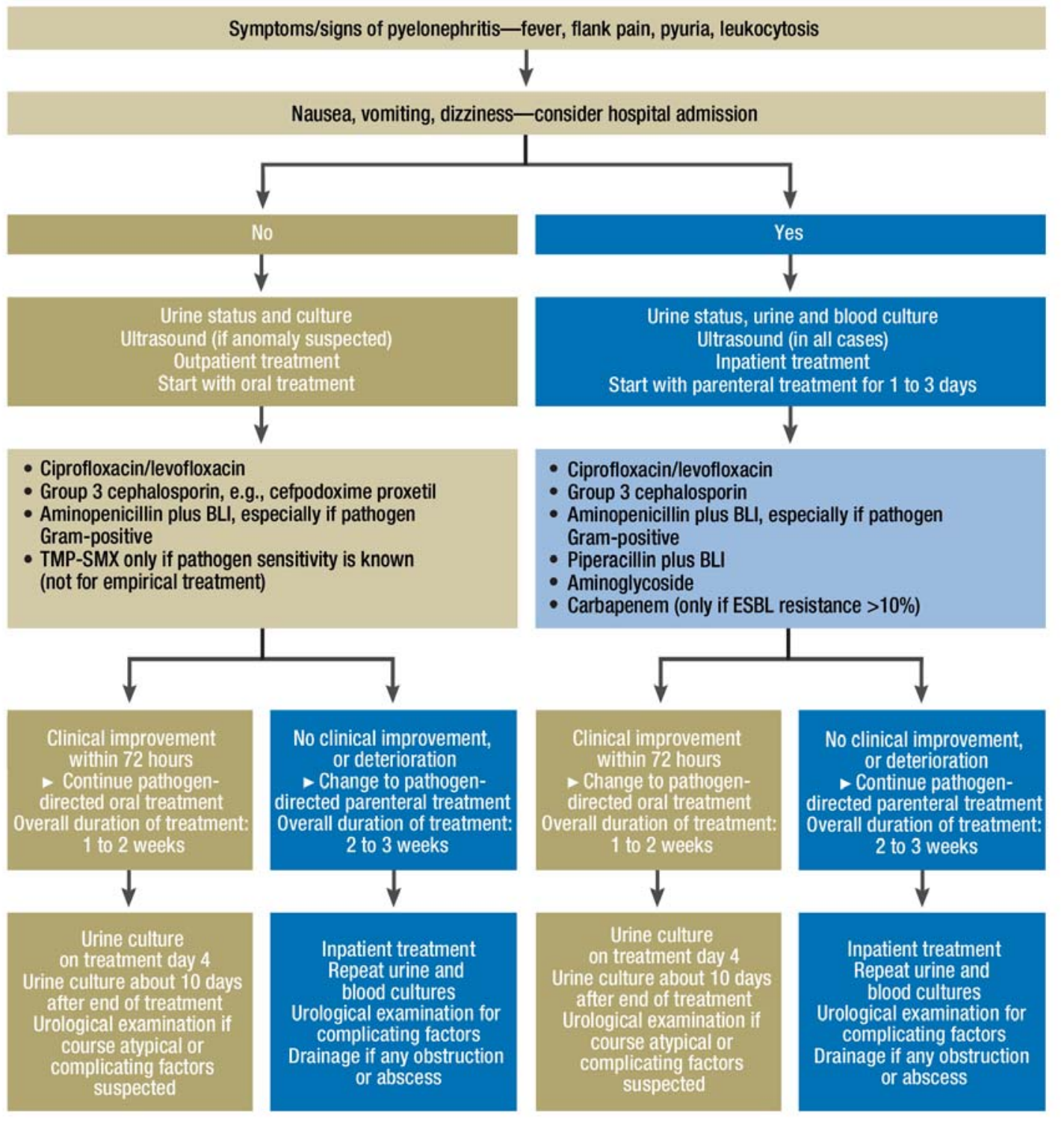

Clinical procedure in acute uncomplicated pyelonephritis in adult women (2).

TMP-SMX, trimethoprim plus sulfamethoxazole; BLI, beta-lactamase inhibitor; ESBL, extended-spectrum beta-lactamase 


\section{KEY MESSAGES}

- Uncomplicated urinary tract infections (UTIS) are responsible for a large proportion of all antibiotic prescriptions; resistance to antibiotics in the pathogens of uncomplicated UTIs is increasing.

- For this reason, in treating UTIs, recommendations for antibiotics must take into account not just factors relating to the efficacy of the antibiotics, but also, especially, factors relating to their sustainability.

- For treatment of uncomplicated cystitis, the first-line recommendation is for antibiotics that are predominantly used only for this indication, such as: fosfomycin trometamol, nitrofurantoin, pivmecillinam.

- For oral treatment of uncomplicated pyelonephritis, the first-line recommendation is for fluoroquinolones, because they have better efficacy data.

- Asymptomatic bacteriuria (ASB) should only be treated in a few exceptional cases, such as during pregnancy or before urinary tract interventions that are expected to damage the mucosa.

Dr. Naber has received fees for various activities from Bayer-Vital, Bionorica, Daiichi-Sankyo, MerLion, Mucos-Pharma, Janssen-Cilag, Johnson and Johnson, Pierre Fabre, Sanofi-Aventis, and Zambon.

Dr. Schmiemann declares that he has no conflict of interest.

Manuscript received on 31 January 2011, revised version accepted on 14 February 2011.

Translated from the original German by Kersti Wagstaff, MA

\section{REFERENCES}

1. Gupta K, Hooton TM, Naber KG, Wullt B, Colgan R, Miller LG, et al.: International clinical practice guidelines for the treatment of acute uncomplicated cystitis and pyelonephritis in women: A 2010 update by the Infectious Diseases Society of America and the European Society for Microbiology and Infectious Diseases. Clin Infect Dis 2011; 52: e103-20.

2. Wagenlehner FME, Schmiemann G, Hoyme U, et al.: Epidemiologie, Diagnostik, Therapie und Management unkomplizierter bakterieller ambulant erworbener Harnwegsinfektionen bei erwachsenen $\mathrm{Pa}$ tienten. S-3 Leitlinie der Arbeitsgemeinschaft Wissenschaftlicher Medizinischer Fachgesellschaften (AWMF) AWMF-Register-Nr 043/044 2010 [cited 2010 October]; Available from: www.uniduesseldorf.de/AWMF/

3. Grabe M (chairman) BM, Bjerklund-Johansen TE, Botto $H$, et al.: Guidelines on urological infections. In: EAU (ed.): European Association of Urology Guidelines. Arnhem, The Netherlands: European Association of Urology 2010; 1-110.

4. Schmiemann G, Kniehl E, Gebhardt K, Matejczyk MM, HummersPradier $\mathrm{E}$ : The diagnosis of urinary tract infection: a systematic review. Dtsch Arztebl Int 2010; 107(21): 361-7

5. Phillips B, Ball C, Sackett D, Badenoch D, Straus S, Haynes B, Dawes M: Oxford Centre for Evidence-based medicine-levels of evidence (March 2009). 1999 [Available from: www.cebm.net/ index.aspx?0=1025]

6. Wagenlehner FME, Hoyme U, Fünfstück R, et al.: Epidemiologie, Diagnostik, Therapie und Management unkomplizierter bakterieller ambulant erworbener Harnwegsinfektionen bei erwachsenen Patienten. S3-Leitlinie AWMF-Register-Nr. 043/044, Harnwegsinfektionen. 2010 Kurzfassung [Available from: www.awmf.org/uploads/ tx_szleitlinien/043-044k_S3_Harnwegsinfektionen.pdf]
7. Wagenlehner FME, Hoyme U, Fünfstück R, et al.: Epidemiologie, Diagnostik, Therapie und Management unkomplizierter bakterieller ambulant erworbener Harnwegsinfektionen bei erwachsenen Patienten. S3-Leitlinie AWMF-Register-Nr. 043/044, Harnwegsinfektionen. 2010 Langfassung [Available from: www.awmf.org/uploads/ tx_Szleitlinien/043-044I_S3_Harnwegsinfektionen.pdf]

8. Wagenlehner FME, Hoyme U, Fünfstück R, et al.: Epidemiology, diagnostics, therapy and management of uncomplicated bacterial community acquired urinary tract infections in adults. S3 Guideline AWMF-Register-Nr. 043/044, Urinary Tract Infections. 2010 Urologenportal [Available from: www.awmf.org/leitlinien/detail/ II/043-044.html]

9. Wagenlehner FME, Hoyme U, Fünfstück R, et al.: Epidemiologie, Diagnostik, Therapie und Management unkomplizierter bakterieller ambulant erworbener Harnwegsinfektionen bei erwachsenen $\mathrm{Pa}$ tienten. S3-Leitlinie AWMF-Register-Nr. 043/044, Harnwegsinfektionen. 2010 Urologenportal [Available from: www.urologenportal. de/index.php?id=113\&frame=awmf

10. Falagas ME, Kotsantis IK, Vouloumanou EK, Rafailidis PI: Antibiotics versus placebo in the treatment of women with uncomplicated cystitis: a meta-analysis of randomized controlled trials. J Infect 2009 58: $91-102$.

11. Richards D, Toop L, Chambers S, Fletcher L: Response to antibiotics of women with symptoms of urinary tract infection but negative dipstick urine test results: double blind randomised controlled trial. BMJ 2005; 16; 331(7509): 143.

12. Christiaens TC, De Meyere M, Verschraegen G, Peersman W, Heytens S, De Maeseneer JM: Randomised controlled trial of nitrofurantoin versus placebo in the treatment of uncomplicated urinary tract infection in adult women. Br J Gen Pract 2002; 52(482): 729-34.

13. Johnson L, Sabel A, Burman WJ, et al.: Emergence of fluoroquinolone resistance in outpatient urinary Escherichia coli isolates. Am J Med 2008; 121: 876-84

14. Metlay JP, Strom BL, Asch DA: Prior antimicrobial drug exposure: a risk factor for trimethoprim-sulfamethoxazole-resistant urinary tract infections. J Antimicrob Chemother 2003; 51: 963-70.

15. Wagenlehner FM, Wagenlehner C, Savov 0, Gualco L, Schito G, Naber KG: Clinical aspects and epidemiology of uncomplicated cystitis in women. German results of the ARESC Study. Urologe A 2010; 49: 253-61.

16. Warren JW, Abrutyn E, Hebel JR, Johnson JR, Schaeffer AJ, Stamm WE: Guidelines for antimicrobial treatment of uncomplicated acute bacterial cystitis and acute pyelonephritis in women. Infectious Diseases Society of America (IDSA). Clin Infect Dis 1999; 29: 745-58.

17. McNulty CA, Richards J, Livermore DM, et al.: Clinical relevance of laboratory-reported antibiotic resistance in acute uncomplicated urinary tract infection in primary care. J Antimicrob Chemother 2006; 58: 1000-8.

18. Paterson DL: "Collateral damage" from cephalosporin or quinolone antibiotic therapy. Clin Infect Dis 2004; 38 Suppl 4: 341-5.

19. Linnebur SA, Parnes BL: Pulmonary and hepatic toxicity due to nitrofurantoin and fluconazole treatment. Ann Pharmacother 2004; 38: 612-6.

20. Nicolle LE, Bradley S, Colgan R, Rice JC, Schaeffer A, Hooton TM: Infectious Diseases Society of America guidelines for the diagnosis and treatment of asymptomatic bacteriuria in adults. Clin Infect Dis 2005; 40: 643-54.

21. Karbach U, Schubert I, Hagemeister J, Ernstmann N, Pfaff H, Höpp HW: Physicians' knowledge of and compliance with guidelines: An exploratory study incardiovascular diseases. Dtsch Arztebl Int 2011; 108(5): $61-9$

22. Wagenlehner FME, Schmiemann G, Hoyme U, Fünfstück R, Hummers-Pradier E, Kaase M, Kniehl E et al.: S3-Leitlinie - Anwenderversion Deutsche Gesellschaft für Urologie (DGU). Empfehlungen zu Therapie und Management unkomplizierter bakterieller ambulant erworbener Harnwegsinfektionen bei erwachsenen Patienten aus 
der nationalen S3-Leitlinie „Unkomplizierte Harnwegsinfektionen“. Urologe 2011; 50: 153-69.

23. Wagenlehner FME, Schmiemann G, Hoyme U, Fünfstück R, et al.: S3-Leitlinie: Epidemiologie, Diagnostik, Therapie und Management unkomplizierter bakterieller ambulant erworbener Harnwegsinfektionen bei erwachsenen Patienten. Nieren- und Hochdruckkrankheiten 2011; 40: 2-20.

24. Schmiemann G, Gebhardt K, Matejczyk M, Hummers-Pradier E: DEGAM-Leitlinie Nr. 1: Brennen beim Wasserlassen - Update 2009. Düsseldorf: Omikron publishing 2009.

25. Zalmanovici Trestioreanu A, Green H, Paul M, Yaphe J, Leibovici L: Antimicrobial agents for treating uncomplicated urinary tract infection in women. Cochrane Database Syst Rev 2010: CD007182.

\section{Corresponding author}

Prof. Dr. med. Florian M. E. Wagenlehner

Klinik und Poliklinik für Urologie, Kinderurologie und Andrologie

Universitätsklinikum Giessen und Marburg GmbH, Standort Giessen

Justus-Liebig-Universität Giessen

Rudolf-Buchheim-Str. 7

35392 Giessen, Germany

Wagenlehner@AOL.com

(2) For eReferences please refer to:

www.aerzteblatt-international.de/ref2411

eTable available at:

www.aerzteblatt-international.de/11m0415 


\section{CLINICAL PRACTICE GUIDELINE}

\section{Uncomplicated Urinary Tract Infections}

Florian M. E. Wagenlehner, Udo Hoyme, Martin Kaase, Reinhard Fünfstück,

Kurt G. Naber, Guido Schmiemann

\section{eREFERENCES}

e1. Lutters M, Vogt-Ferrier NB: Antibiotic duration for treating uncomplicated, symptomatic lower urinary tract infections in elderly women. Cochrane Database Syst Rev. 2008; (3): CD001535.

e2. Guinto VT, De Guia B, Festin MR, Dowswell T: Different antibiotic regimens for treating asymptomatic bacteriuria in pregnancy. Cochrane Database Syst Rev. 2010; (9): CD007855.

e3. Costelloe C, Metcalfe C, Lovering A, Mant D, Hay AD: Effect of antibiotic prescribing in primary care on antimicrobial resistance in individual patients: systematic review and meta-analysis. BMJ 2010; 340: c2096.

e4. Little P, Moore MV, Turner S, Rumsby K, Warner G, Lowes JA, et al.: Effectiveness of five different approaches in management of urinary tract infection: randomised controlled trial. BMJ 2010; 340: c199.

e5. Bleidorn J, Gagyor I, Kochen MM, Wegscheider K, HummersPradier E: Symptomatic treatment (ibuprofen) or antibiotics (ciprofloxacin) for uncomplicated urinary tract infection? Results of a randomized controlled pilot trial. BMC Med 2010; 8: 30.

e6. Rafalsky V, Andreeva I, Rjabkova E: Quinolones for uncomplicated acute cystitis in women. Cochrane Database Syst Rev. 2006; 3 : CD003597.

e7. Katchman EA, Milo G, Paul M, Christiaens T, Baerheim A, Leibovici $L$ : Three-day vs longer duration of antibiotic treatment for cystitis in women: systematic review and meta-analysis. Am J Med 2005; 118: 1196-207.

e8. Lutters M, Vogt N: Antibiotic duration for treating uncomplicated, symptomatic lower urinary tract infections in elderly women. Cochrane Database Syst Rev. 2002; (3): CD001535. 